\title{
БАБИНСЬКА КУЛЬТУРОІЕНЕЗА
}

Розглядається проблема культуротенези в археологї на прикладі дніпро-донської бабинської культури.

Ключові слова: культурогенеза, бронзовий вік, культурне коло Бабине.

Вступ. Культурогенетична проблематика в археології належить до високопорядкових, найбільш складних, заплутаних, дискусійних, відповідальних, а подекуди й спекулятивних. На наше глибоке переконання, в ідеалі братися за розв'язання питань походження археологічних культур варто за умов досягнення високого рівня дослідженості відповідних археологічних утворень, який визначається достеменністю культурного ареалу, рівномірністю його вивчення; кількісними та якісними показниками джерельної бази, їі упорядкування й систематизації; мірою об'єктивності характеристик i критеріїв самої археологічної культури, надійністю виявлених в ній внутрішніх зв'язків i взаємозумовленостей, а відтак - ступенем i певністю прогнозування; адекватністю оцінки рівня однорідності чи локальної варіативності археологічного френомену, чіткості його культурно-таксономічної систематики; ступенем розробки питань внутрішньої періодизації та відносної хронології, а також багатьох інших аспектів, які виступають індикаторами повноти, комплексності й системності вивчення археологічного феномену.

Крім того, успішні культурогенетичні студії є неможливими без розуміння місця досліджуваного археологічного утворення на тлі доби й оточуючих культур, причому як у синхронному, так і діахронному вимірах. Не кажу вже про бажаність долучення до системи аргументації ( ) Р. О. ЛИТВИНЕНКО, 2021 всіляких даних природничих наук, починаючи від антропологічних та палеокліматичних і завершуючи ізотопними й генетичними. Проте, ці установки є теоретичними або методичними, на практиці зазвичай трапляеться інакше. I на те існують об’єктивні, а ще більше суб'єктивні причини.

3 огляду на проблематику збірника на пошану В. В. Отрощенка, хочемо запропонувати сюжет, що не претендуе на вичерпність і всеосяжність, присвячений культурогенезі однієї з археологічних культур, яка входить до складу культурного кола / області Бабине, яке, в свою чергу, включають до блоку посткатакомбних культурних утворень Східної Свропи (Мимоход 2005), - дніпро-донської бабинської культури (ДДБК) (Литвиненко 2009b). Бабинське культурне коло за останню чверть століття перетворилось на одне 3 найкраще досліджених археологічних утворень бронзового віку півдня Східної Свропи. Ключова ж його культура - ДДБК - у багатьох відношеннях (упорядкування й систематизація джерельної бази, всебічне вивчення археологічних комплексів і категорій матеріальної культури, насамперед 3 курганних могильників, розробка п'ятиступеневої періодизації, розробка відносної хронології на широкому тлі від Центральної Свропи до Уралу та Кавказу, виявлення чіткої хронологічної динаміки культурного ареалу, гендерні аспекти бабинського соціуму й культури тощо) видається чи не найкраще дослідженою серед археологічних утворень бронзового віку Надчорномор'я. Звичайно, ДДБК ще далека від того теоретично бажаного рівня вивченості, який ми окреслили вище, натомість навіть його нинішній стан надає підстави щонайменше для постанови культурогенетич- 
них питань і деяких пропозищій щодо їхнього розв'язання.

Історіографія. Перша концепція походження бабинської культури (багатоваликової кераміки) генерувалася протягом 1960x pp. і була офрормлена спочатку в дисертації С. Н. Братченка, а дещо згодом опублікованою в низці праць автора. Критично використовуючи і розвиваючи спостереження попередників, насамперед гіпотезу Б. О. Латиніна щодо катакомбних витоків пам'яток 3 багатоваликовою керамікою (Латынин 1964, с. 63-70), С. Н. Братченко розглядав генезу бабинської культури в контексті загального синстадіального процесу, що охопив Східну й Центральну Європу та завершився зміною культур шнурової кераміки почетом культур з рельефною, в тому числі валиковою й прокресленою, орнаментацією посуду. В Дніпро-Донському ареалі, а також на сусідніх теренах Поволжя і Правобережної України цей процес супроводжувався значними культурними зрушеннями, взаємопроникненнями степових і лісостепових катакомбних елементів (з перевагою останніх), появою пам'яток змішаного характеру, подальшою інтеграцією та оформленням культури нового типу, яка увійшла до складу посткатакомбної та постшнурової спільноти. Причини та внутрішній зміст цих складних процесів залишалися незрозумілими та не піддавалися вилученню з археологічних джерел. Поширення культури на теренах Надчорномор'я розумілося як результат міграційних процесів (Братченко 1971, с. $334,342-343$; 1976, с. $117-118$; $1977 ; 1985$, с. 457-458). Парадоксально, але перша концепція бабинської культурогенези С. Н. Братченка виявилася напрочуд вдалою по суті, глибокою за змістом і такою, що випереджала тогочасний рівень вивченості та аналізу цього археологічного френомену.

Ця концепція знайшла подальший розвиток і трансформації у працях археологів. Мабуть, найбільш значущим їі доповненням став підхід, згідно якого становлення бабинської культури розглядалося в контексті певного відновлення чи реанімації ямного культурного (етнічного) компоненту та включення його, поряд 3 катакомбним, до складу культурного субстрату Бабине. Ця точка зору, що її висловили з дещо відмінними авторськими акцентами I. Ф. Ковальова (Ковалева 1981, с. 75-76; 1987a, с. 214 $222 ; 1987 b$, с. 22-23, 30) та I. О. Післарій (Писларий 1983 , с. 15,$19 ; 1991$, с. $60-62$; Pâslaru 2006, p. 117-120), певною мірою сприяла розумінню чинників бабинської культурогенези. До речі, згодом 3 приводу циклічного відродження в бабинському поховальному обряді та ідеології пізньоямних традицій став писати i С. Н. Братченко (Братченко 1995a, с. 23; 1995b, c. $87 ; 2006$, с. 225). Зазначені ідеї щодо ямно-бабинської генетичної спадковості різною мірою знайшли відображення у дослідженнях інших регіональних груп Бабине (КБК), насамперед дністровсько-прутського регіону (Дергачев 1986, с. 14-143; Іванова, Тощев 2018; та ін.).

Альтернативну концепцію утворення бабинської культури (КБК) запропонувала С. С. Березанська (Березанская 1979, с. 6; 1986, c. 41-42). При цьому авторка, треба віддати їй належне, висунула теоретичне обгрунтування перспективного, на їі думку, напрямку культурогенетичних дослідів, суть якого полягала у вияві складових компонентів КБК, визначенні питомої ваги кожного з них, а також встановленні всіх етапів передуючого розвитку, в тому числі тих глибинних ланок, вплив яких проявлявся у новонародженій культурі «начебто через “покоління”» (Березанская 1986, с. 41). Щоправда, сама дослідниця обійшлася без здійснення запропонованих нею аналітичних процедур, що й відбилося на отриманих результатах. Культура у своїй основі сприймалася нею як місцева, а утворення 㣙 варіантів розцінювалося як одночасне, чим заперечувався осередковий сценарій культуроґенези та мігращійний варіант iï поширення. Наявність локальних варіантів пояснювалась, перш за все, різницею місцевого підгрунтя, на якому ці варіанти утворювалися: ямна (буджацька група), катакомбна, середньодніпровська культури та пам'ятки типу Перун. Одним з необхідних чинників культуротворення C. С. Березанська вважала наявність зовнішніх імпульсів чи міграційних хвиль, а у випадку 3 Іенезою КБК пов'язувала витоки такого поштовху з носіями колісничних культур.

Ця остання сюжетна лінія 3 часом набула певного розвитку й перетворилась у ще одну концепцію походження бабинської культури, висунуту В. В. Отрощенком. Сутність їі полягає у розумінні культури Бабине, як продукту південноуральського вогнища культурогенези. Загальний культуротворчий сценарій зводився до просування воїнських колісничних загонів синташтинської культури з Південного Уралу на захід через Середне Поволжя до Середньої Донщини, де вони, з одного боку, стимулювали утворення ДВАК, а з другого - поклали кінець середньодонській катакомбній культурі, витиснувши рештки їі населення на південь i тим самим започаткувавши ії трансформацію в бабинську культуру (Отрощенко 1996, с. 30; 1998 , с. $56 ; 2002$, с. $14-15 ; 2003$, с. 76 ; та ін.).

Своєрідним переспівом концепції В. В. Отрощенка, причому дуже спрощеним і вихолощеним, відірваним від загального тла культурно-історичних процесів бронзового віку Східної Свропи, можна вважати підхід С. М. Санжарова, який щойно наведений процес впливів і трансформацій територіально зсунув з Середньої Донщини на Сіверськодонеччину і замінив синташтинську культуру на абашевську (Санжаров 2010, с. 405-406, 433-434).

На окрему увагу заслуговуе оригінальна гіпотеза I. Т. Чернякова, згідно якої бабинська 
культура (КБК) є породженням і навіть східним ареалом Балкано-Дунайського осередку культурогенези. На думку дослідника, витоки процесів, що надалі призвели до утворення КБК, слід шукати у розповсюдженні племен катакомбної культури на захід, в ході якого відбувалася асиміляція місцевих степових культур Північно-Західного Причорномор'я i, водночас, витискання частини аборигенного населення до Балкано-Подунав'я та Прикарпаття, на терени сучасних Румунії, Болгарії, Сербії та Угорщини. Ефект «стиснутої демографрічної пружини» призвів до різкого виплеску степового населення 3 Балкано-Дунайського регіону назад на схід, де воно «взяло активну участь у створенні низки культур нової культурно-історичної спільноти, відолої як КБК. Ця зворотна західна хвиля не лише прокотилась по колишній катаколбній культурноісторичній спільноті, але й досягла ВолзькоУральського регіону. Це нове переобборллення було пов'язане з якились певнили політичними подіяли, обборлленнял нових культурних впливів, активного обліну, а також переселеннам різних категорій окрелих груп індоєвропейського населення» (переклад мій - Р. Л.) (Черняков 1996). Гіпотеза, слід зазначити, доволі яскрава та оригінальна, єдина проблема — не має жодної аргументації.

Згадаємо ще одну цікаву версію походження культури Бабине, здебільшого умоглядну й інтуїтивну, що її запропоновав С. А. Григор'єв, на думку якого формування КБК було стимульоване проникненням у Північне Причорномор'я популяції 3 теренів Південного Кавказу (Grigoriev 2002, p. 400).

На наш погляд, жодна 3 наведених точок зору не позбавлена певних вад чи вузьких місць, а тому не може бути прийнятою беззаперечно. Головне, що жодна 3 них не знаходить належної відповідності в усьому комплексі археологічних джерел, не охоплює всієї системи хронологічних взаємозалежностей, належним чином не пояснюе всіх аспектів культурних зв'язків чи впливів. Цьому є доволі банальне пояснення: серед представлених концептуальних підходів немає таких, що являли б собою результат цілеспрямованого, всебічного і поглибленого дослідження, об'єктом якого виступала б уся сукупність археологічних пам'яток культурної області Бабине. Практично всі згадувані гіпотези або базувалися на обмеженій джерельній базі, або носили вузько локальний характер, або ж виникли як побічний продукт іншого дослідження. Натомість варто відзначити, що майже кожна 3 наведених точок зору має якесь раціональне зерно, що не дозволяє повністю їі ігнорувати. При цьому на особливу увагу заслуговуе концепція С. Н. Братченка, яка вирізняеться на тлі інших своєю глибиною, проникливістю, опрацьованістю на теоретичному й джерелознавчому рівнях, а тому розці- нюється нами як найпереконливіша i, водночас, придатна для розвитку й удосконалення.

Проблемам бабинської культурогенези присвячено низку праць автора цих рядків, підготовлених в рамках роботи над докторською дисертацією і згодом, за їі мотивами (Литвиненко 2007a; 2009a; 2009b; 2009c; 2010b; 2011; $2011 \mathrm{a} ; 2011 \mathrm{~b} ; 2011 \mathrm{c} ; 2013)$. Продовжуючи цю тему, пропонуємо дещо розширений, проте далеко не вичерпний, сюжет, присвячений проблемі культурогенези ДДБК, як первинної та найкраще дослідженої культури Бабинського кола, що його було озвучено автором на кондеренції 2017 р. у Винниках (Литвиненко 2017).

Принципи, методика й вихідні позиції. У розв'язанні проблем культурогенези від початку ми керувались індуктивним методом, згідно якого при побудові висновків, гіпотез і концепцій умовивиди відштовхуються від фрактів. В нашому випадку первинними фрактами виступають археологічні джерела, а саме матеріали курганних могильників ДДБК, що є найбільш масовим, повніше і краще дослідженим, систематизованим і упорядкованим, хронологічно діагностованим видом археологічних свідоцтв, порівняно 3 даними менш чисельних, слабко і фрагментарно вивчених, культурно-таксономічно і хронологічно недиференщійованих поселень.

Курганні могильники, по своїй суті, є своєрідними археологічними ансамблями - підсистемами комплексу пам'яток, згрупованих у взаємопов'язані підрозділи за фрункціональним принципом (Бочкарев 1990, с. 53). Ці підсистеми складаються зі замкнених і напівзамкнених комплексів, які представляють собою сполучення контекстуально i фрункціонально пов'язаних споруд, об'єктів і артедрактів певних типів, що своєю упорядкованою і регулярно повторюваною сукупністю та співвідношеннями характеризують конкретну археологічну культуру (Бочкарев 1990, с. 93; Клейн 1991, с. 391). Першим кроком в дослідницькій процедурі став аналіз могильників ДДБК - розчленування бабинського поховального комплексу на структурні елементи на рівні курганного будівництва, могильних споруд, решток небіжчика, поховального супроводу, слідів додаткових обрядово-ритуальних дій тощо.

Другим кроком стала оцінка цих структурних елементів або комбінацій елементів с точки зору їхніх можливих витоків. Щось подібне в методичному сенсі свого часу пропонувала С. С. Березанська (1986, с. 41), але реалізувати цього не змогла. Оцінка структурних складових поховальних пам'яток ДДБК засвідчуе, що цей набір елементів не є гомогенним і може бути поділеним щонайменше на три групи, відмінні за своїм можливим походженням: I) традиції; II) зовнішні впливи; III) інновації (рисунок).

I. Tpaдиuї. В археологічному образі могильників ДДБК доволі виразно простежуеться комплекс характеристик, який своїми витока- 


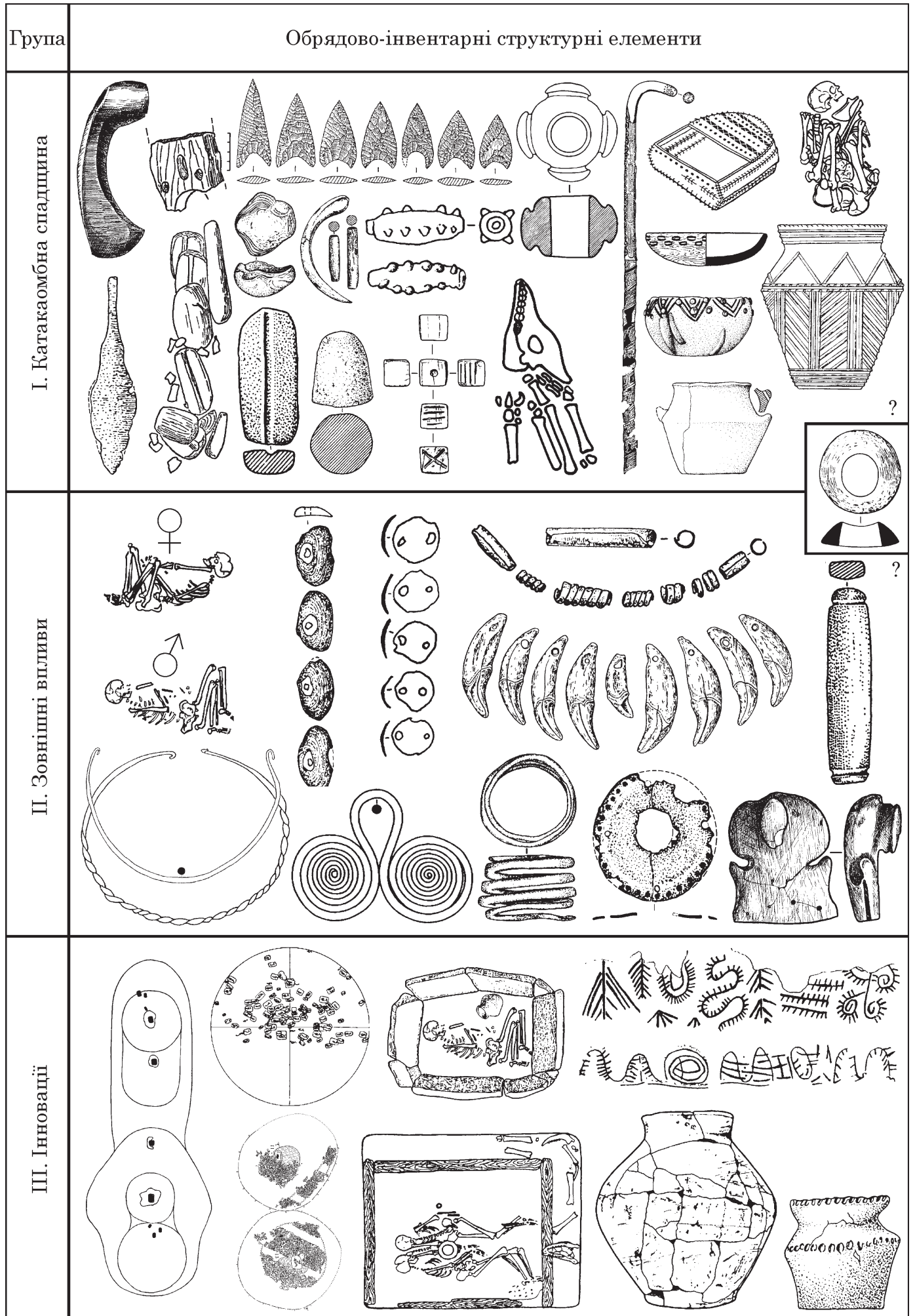

Схема генетичної структури дніпро-донської бабинської культури

ми уходить у місцеве передуюче середовище середньобронзового віку, представлене культурами катакомбної області (рисунок: I). Причому йдеться насамперед про катакомбні культури Донецько-Донського регіону - донецьку, середньодонську (харківсько-воронезьку), волгодонську, які С. Н. Братченко у своїх останніх працях об'єднував у складі донецько-донськоӥ (донської) катакомбної культури, в якій він виділяв низку локальних груп, названих за басейнами річок (Братченко 2004, с. 179-185; Братченко, Санжаров 2001, с. 91-96; Литвиненко $2011 b$, с. 182). Спадковість ця проявляеться на рівні поховальної обрядовості та матеріального комплексу (Литвиненко 2002; 2009a; 2011b). Навіть якщо не брати до уваги наскрізні для брон- 
зового віку Східної Свропи ознаки (курганний обряд, основний і впускний стратиграфрічний статус, скорчені пози небіжчиків тощо), ДДБК визначаеться доволі специфічним набором характеристик, що мають достеменно катакомбне коріння: поховання - «пакунки» (Литвиненко 2011d), супровід небіжчика "виробничими наборами» реманенту (Литвиненко 1998b; 2015), сагайдаками зі стрілами (Литвиненко 1998а; 2019 , с. 315 , рис. 2), гральними кістками (Рогудеев 2018), «шкурами / опудалами» тварин (Литвиненко 1997). Окремі з перелічених характеристик мають глибші, ніж катакомбна доба, витоки, оскільки простежуються ще в ямній культурі ранньої бронзи, наприклад поховання «пакунків» і «виробничі набори». В матеріальному комплексі катакомбна спадшина (причому пізньокатакомбна) чітко фріксуеться в наступному: частині металокомплексу (костромські сокири, деякі типи ножів; Братченко 1976 , с. $150 ; 1985$, с. 454 ; Черных 1995, с. 16 ; Гак 2005; Литвиненко 2006b, с. 40-44, 51); кременевих виробів (виїмчасті вістря стріл) (Братченко 2006, с. 271, 291; Литвиненко 1998а; 2011a, с. 191); арсеналі реманенту стрілоробів з категоріально і типологічно характерним набором інструментів (Литвиненко 1998b; 2011a, с. 191; 2015; Санжаров 2008, с. 68-70); дерев'яному посуді та різних ємностях, зокрема 3 металевими деталями (ритуальні чаші, скриньки, пенали-фрутляри для виробничого реманенту) (Литвиненко 2004b; 2011a, с. 190-191; 2019, рис. 4: 12); частині керамічного посуду, зокрема струнких тричасних формах з багатоваликовим декором і трикутно-паркетно-ялинковими орнаментальними композиціями (Братченко 1977, с. 32 ; Санжаров 2010, с. 257-266; Литвиненко 2011a, с. 188-190, рис. 2; 3); окремих категоріях прикрас і вбрання (фаянсові бородавчасті пронизки, кістяні кільця-пряжки) (Литвиненко 2011a, с. 192-195). Збереглися і притаманні катакомбній культурі норми супроводження деяких соціальних / гендерних груп небіжчиків такими атрибутами поховального приданого, як владні атрибути (булави й сокири-молоти 3 кам'яними навершниками катакомних типів, дерев'яна гирлига-посох - у чоловіків) (Братченко 2006, с. 291; Санжаров 2010, с. 347; Литвиненко 2020а, с. 94, рис. 4; Отрощенко 2020, c. 130-133) або набори астрагалів (переважно чоловічого приданого, з тяжінням його до хлопчаче-юнацького віку) (Братченко 2008, с. 202; 2009, с. 193; Литвиненко 2005c; 2011b, с. 188).

На тлі цього виразного й потужного донецько-донського катакомбного компоненту, в ДДБК виділяється питомо значно менший i слабший елемент, пов'язаний 3 інгульською (дніпро-азовською) катакомбною культурою (ІКК). Проявляеться він лише в керамічному посуді, а саме в серії напівсфреричних чаш з характерним декором і амфорок з парними вушками для підвішування.
II. Зовнішні впливи. Поховальний комплекс ДДБК включає доволі характерний комплект ознак, які неможливо вивести з місцевого передуючого культурного середовища, оскільки вони там відсутні (рисунок: II). Ці ознаки, як і в попередній групі, стосуються поховального ритуалу і матеріального комплексу. Притаманні ДДБК норми поховальної практики є унікальними не лише для бронзового віку Північного Причорномор'я, а й, видається, для більшості областей Східної Свропи. Йдеться, насамперед, про поховальну норму протиставлення небіжчиків на ґендерному рівні, виявлену майже тридцять років тому В. В. Отрощенком (1992), а згодом досліджену автором (Литвиненко 2007b), згідно якої небіжчики чоловічої та жіночої статі укладалися за принципом бінарної антитези (протилежні орієнтація, бік) і супроводжувалися гендерно відмінним поховальним приданим: чоловіки - зброєю, інсигніями влади й певними категоріями вбрання (кістяними пряжками, металевими гривнами); жінки - розмаїтим набором прикрас, деякі категорії якого є винятково жіночими (металеві бінокулярні підвіски та ін.).

В матеріальному комплексі ДДБК з'являеться новий набір артефактів, який не має жодного підгрунтя в передуючому катакомбному середовищі, проте знаходить надійні джерела зовні. Показовим $е$ те, що всі ці новації характеризують здебільшого вбрання і гарнітур прикрас: мідно-бронзові дротяні шийні гривни, спіральні браслети, бінокулярні / біноклеподібні підвіски, спіральні та бляшані рурчасті пронизки, нашивна дископодібна бляха з пуансонним декором, нашивні півсферичні круглі бляшки, нашивні стулки мушель, паски 3 кістяними гачково-планковими пряжками ${ }^{1}$, кам'яні захисні платівки лучника тощо. До џьго списку додаються й деякі категорії (підвіски з ікл собачих і зубів оленя), що формально відомі в ямному й катакомбному середовищі, але використовувались там в дещо інший спосіб і кількості, ніж у ДДБК, де вони входили до гарнітуру прикрас у сполученнях з деякими вищеназваними атрибутами, подібно тому, як це

1. Якщо в оцінці вектору походження гачково-планкових пряжок дослідники е більш-менш солідарними (Гершкович 1986, с. 139-142, рис. 8; Литвиненко 2009, с. 59-60, рис. 4; Мимоход 2018, c. $35-35$, рис. 3 ), то питання щодо виникнення кільцевих пряжок залишаеться відкритим. 3 одного боку, цим кільцям відомі чисельні аналогії в ранньобронзових культурах Центральної Європи (Lytvynenko 2013, fig. 3-6, 8, 10), а з іншого - в безпосередньо передуючому ДДБК пізньокатакомбному горизонті Донецько-Донського регіону (комплекси бахмутського типу або з ялинковим декоруванням кераміки) також відомі кільцяпряжки раннього типу 1 , що дае підстави відносити їх до катакомбного спадку (Литвиненко 2011b, с. $192-195$, рис. $4-7)$. 
мало місце в їхньому первинному культурному осередкові.

Весь цей комплект характеристик, не маючи місцевого коріння, знаходить виразні відповідники в культурах / групах раннього бронзового віку Центральної Свропи й синхронних утвореннях середнього бронзового віку Південно-Східної Свропи (Нижнього Подунав'я): стжижовська, межановицька, унетицька, нітрянська, Унтервельблінг, Штраубінг, Зінген, Адлерберг, Ріс, Некар, Рона / Воллес, Полада, Гата-Візельбург, Кішапоштаг, Ватья, Муреш / Періям та ін. (Литвиненко 2009а; 2011a; Lytvynenko 2013; Grigoriev 2019). Особливо наголосимо, що з цими західними культурами ДДБК демонструє не поодинокі паралелі, а цілі серії стійких відповідників (від 5 до 10 позицій 3 кожною) (Lytvynenko 2013, p. 124-132, fig. 3; Grigoriev 2019, p. 229—235, tab. 2), до яких у більшості випадків додається і гендерне протиставлення небіжчиків. Ці обставини, до речі, дають підстави для надійної синхронізації ДДБК з культурами Карпато-Подунав'я, яке, за різними оцінками, окреслюеться в межах періодів $\mathrm{Br} \mathrm{A} 1 \mathrm{~b}-\mathrm{A} 2 \mathrm{a}$ або $\mathrm{Br} \mathrm{A} 1 \mathrm{c}$ модернізованих схем періодизації П. Рейнеке (Литвиненко 2009b, c. 18; Lytvynenko 2013, p. 134; Grigoriev 2019, p. 234-235).

В мозаїці археологічного образу ДДБК $є$ й декілька фрагментів, які також доволі впевнено можна вважати зовнішніми запозиченнями, але 3 іншого середовища - сусідньої зі сходу лолінської культури (Мимоход 2013). Стосуються вони деяких елементів поховального обряду й матеріального комплексу: підбійно-катакомбні могильні споруди, лопатки тварин у похованнях, кістяні «дзиги», деякі типи фраянсового намиста (Литвиненко 2004a; 2005b).

III. Інновацї̈. Ця група характеристик об'єднуе такі складові культурного комплексу ДДБК, які не вдається пов'язати з місцевим передуючим середовищем і зовнішніми впливами (рисунок: III). Їх, на перший погляд, виявляється не так багато, проте вони є i, вочевидь, демонструють внутрішні процеси культуротворення: специфічне курганне будівництво (започаткування практики зведення довгих могил, розмаїта кам'яна архітектура) (Ковалева 1988; Литвиненко 2000, 2010а; Макаревич 2009); нормативи локалізації впускних поховань в кургані (Литвиненко 2012); дерев'яні рамні гробниці та кам'яні скрині (Литвиненко 1999а) ${ }^{1}$; своерідний керамічний комплекс (починаючи від великих стандартизованих корч i завершуючи асиметричними, "незграбними» ребристими посудинками) та особливості його

1. Натомість, може виявитися, що дерев'яні рамні конструкції ДДБК також мають західні, епішнурові, витоки, на що натякае фракт використання в чомусь подібних конструкцій в протоунетицьких могильниках (Stuchlik 2000). застосування в поховальному ритуалі (Литвиненко 1999b; 2016); нарешті, самобутня знакова система кодування й передачі інформащії світоглядно-релігійного і ритуального змісту, відома за керамічним посудом (Ковалева 1989, с. 57 , рис. 12 ; Пряхин, Захарова 1996 , с. $60-63$, рис. 2; Отрощенко 2005) тощо.

Оцінка та інтерпретація. Як продемонстрував структурний аналіз археологічного комплексу ДДБК, в ньому виявляеться декілька складових блоків. На особливу увагу з них заслуговують два перші, оскільки вони, виступаючи базовими, надають вихідні дані для розуміння процесу культурогенези ДДБК. Отже, в цій бабинській культурі чітко й виразно фріксуеться передуючий місцевий компонент, в основі своїй репрезентований донеиько-донською катаколбною культурою та в незначній мірі - інгульською катаколбною культурою. Цей фракт надійно засвідчуе присутність місцевого катакомбного субстрату в генезі ДДБК. Виразність і презентабельність цього субстрату (донецько-донського) в усьому культурному ареалі дає підстави вважати його базовою основою у формуванні ДДБК. Інгульський катакомбний елемент, судячи з його незначної долі, був другорядним. А той фракт, що керамічний посуд інгульського типу трапляеться не по всіх теренах ДДБК, а лише в західній частині ареалу (Надазов'я, Наддніпрянщина, Поінгулля), де в пізньокатакомбний час домінує інгульська катакомбна культура, визначає регіональну роль інгульського субстрату. Дуже важливою та цікавою видається й така обставина, що згаданий інгульський елемент (кераміка) походить винятково з жіночих поховань (!), що натякає на інкорпорацію саме жіночого інгульського компоненту до соціуму ДДБК, який міг відбуватися через шлюби.

Зовнішні впливи, витоки яких вперше виявлено нами в середовищі ранньобронзових культур Центральної Свропи (Литвиненко 2001, c. $168 ; 2002$, c. $190 ; 2005$ a, c. $123 ; 2006$ a, c. 228 234), виступали другим ключовим елементом i чинником в культурогенезі ДДБК. Конкретне вогнище цього зовнішнього імпульсу наразі залишається невизначеним. Це могла бути як конкретна культура, наприклад унетицька, 3 якою ДДБК демонструе чимало паралелей, так і коло близьких між собою культур/груп західніше Карпат. Виявлення цьго осередку - це справа найближчої дослідницької перспективи. Спосіб передачі цього імпульсу на відстань щонайменше 1300 км також залишаеться відкритим, адже на проміжній території між відповідними центральноевропейськими культурами / групами та Дніпро-Донецько-Азовським первинним осередком ДДБК наразі не відомі пам'ятки чи знахідки, в яких би можна було вбачати, скажімо, віхи умовного маршруту мігрантів чи культуртрегерів. Втім, як відомо, існують мігращії, що не залишають слідів на 
шляху свого руху, наприклад т. зв. «марш-кидки» на далекі відстані (Клейн 1999, рис. 9). До того ж, значна частина щіеї припустимої дистанції (щонайменше правобережний Український Лісостеп-Полісся) досліджена на предмет пам'яток доби бронзи доволі нерівномірно, а загалом - слабко.

Водночас, ми можемо обгрунтовано припускати, що цей західний культуротворчий імпульс був доволі стрімким, короткочасним i, вочевидь, одноразовим. Про це свідчить та непорушна обставина, що всі ознаки центральноєвропейського впливу фіксуються в ДДБК лише протягом іï раннього періоду, а найвиразніше i масово вони проявляються на початку цього періоду (етап IA), причому лише в первинному, найдавнішому ареалі ДДБК - Дніпро-Донецько-Азовському, де культура формувалась. На етапі ІБ сліди західного імпульсу трапляються поодиноко і представлені вони майже винятково практикою бінарного протиставлення чоловіків і жінок у поховальному обряді, будучі мінімізованими в матеріальному комплексі. До речі, виділена В. В. Отрощенком (1992) жіноча обрядова група виступає в ДДБК надійним хронологічним індикатором, що датуе відповідні поховання в межах етапів IA-ІБ. Цей висновок надійно корелюеться 3 ареалом жіночих поховань цієї обрядової групи: вони локалізуються лише в межах первинного осередку і зоні розширення ареалу ДДБК на етапі ІБ (Литвиненко 2020b, с. 335, рис. 1), в останній - навіть не повсюдно, а лише в районах, наближених до первинного осередку. На всіх наступних етапах ДДБК жодні центральноєвропейські елементи в ДДБК уже не проглядаються.

Згадувані вище нечисельні лолінські прояви фіксуються в пам'ятках різних етапів ДДБК, хоча виразніше - на ранньому. Показово, що всі вони походять з районів Нижньої Донщини - зони контактів між ДДБК і Лолою. Наведені обставини дозволяють розцінювати ці сліди як свідчення взаємин між сусідніми культурами, не виводячи їх на рівень культурогенетичних процесів.

Висновки. Таким чиним, структурний аналіз археологічного комплексу ДДБК дозволив виділити в ньому декілька блоків, відмінних за своєю природою і витоками. Ці блоки розуміються нами як складові елементи бабинського культуротворення i, водночас, ключі до розуміння цього процесу. Базовими субстратом в культурогенезі ДДБК виступав місцевий пізньокатакомбний компонент - донецькодонський, за незначної локальної долі інгульського. Другим ключовим елементом i, найймовірніше, культурогенетичним каталізатором став зовнішній імпульс 3 ранньобронзового культурного середовища Центральної Свропи (унетицька та близькі до неї культури / групи). Найменш зрозумілим залишається спосіб перенесення цього імпульсу на схід (міграція, куль- туртрегери-місіонери чи якийсь інший). Для осягнення змісту процесу бабинської культурогенези важливо враховувати, що він відбувалася на тлі глобальної природно-кліматичної катастрофи кінця раннього - початку середнього суббореалу 3 піком навколо 2200 р. до P. X. (2200 BC cal), яка, вочевидь, спричинила деструкцію потестарних утворень катакомбної культурної області та фрормування на їхньому місці культур посткаткакомбного блоку, зокрема й бабинського кола (Литвиненко 2007a; 2009a; 2009c). Ще одним чинником бабинської культурогенези слід вважати наявність в центрі первинного осередку ДДБК давнього центру металовиробництва на базі міднорудних покладів Бахмутської улоговини (Литвиненко 2005a), дістатись яких, можливо, й прагнули західні мігранти.

Аналіз всіх доступних фрактів дозволяе зробити висновок про те, що бабинська культурогенеза є прикладом реалізації моделі взаємодії двох сценаріїв культурогонії - стилульованої трансборлаиї̈ та запозичення (Массон 1991, c. $7-8 ; 2000$, с. 10$)$.

Тепер залишається протестувати запропоновану на підставі суто археологічних матеріалів культурогенетичну концепцію дослідженнями ДНК.

\section{ЛITЕРАТУРА}

Березанская, С. С. 1979. Основные результаты изучения культуры многоваликовой керамики. В: Моруженко, А.А. (ред.). Проблемы эпохи бронзы юга Восточной Европь. Донецк, с. 4-6.

Березанская, С. С. 1986. Культура многоваликовой керамики. В: Артеменко, И. И. (ред.). Культуры эпохи бронзы на территории Украины. Киев: Наукова думка, с. 5-43.

Братченко, С. Н. 1971. Пам'ятки багатоваликової кераміки. В: Бібіков, С. М. (ред.). Археологія $У_{\kappa}$ раїнської РСР: в 3 т. 1. Київ: Наукова думка, с. 334344.

Братченко, С. Н. 1976. Нижнее Подонье в эпоху средней бронзы. Киев: Наукова думка.

Братченко, С. Н. 1977. К вопросу о сложении бабинской культуры (многоваликовой керамики). В: Телегин, Д. Я. (ред.). Вильнянские курганы в Днепровскол Надпорожье. Киев: Наукова думка, с. 2142.

Братченко, С. Н. 1985. Культура многоваликовой керамики. В: Артеменко, И. И. (ред.). Археология Украинской ССР: в 3 т. 1. Киев: Наукова думка, c. $451-458$.

Братченко, С. Н. 1995а. Пряжки эпохи поздней бронзы и их северокавказские формы. В: Массон, В. М. (ред.). Конвергениия и дивергениия в развитии культур эпохи энеолита - бронзы Средней и восточной Европы. Материалы конфберениии: в 2 ч. II. Санкт-Петербург, с. 8-26.

Братченко, С. Н. 1995b. Соотношение каменной и бронзовой индустрий в энеолите и бронзовом веке. Донские древности, 4, с. 79-92.

Братченко, С. Н. 2004. Прадавня Слобожанщина: Сватівські могили-кургани III тис. до н. е. та майдани. Матеріали та дослідження з археологї̈ Східної України, 2, с. 65-190. 
Братченко, С. Н. 2006. Левенцовская крепость. Палитник культуры бронзового века. Матеріали та дослідження з археології Східної України, 6. Луганськ: СУНУ ім. В. Даля.

Братченко, С. Н. 2008. Олександрівські могиликургани в долині Лугані. Матеріали та дослідження з археологї Східної Украӥни, 8, с. 134-217.

Братченко, С. Н. 2009. Миколаївські могили-кургани в пониззі р. Луганка. Матеріали та дослідження з археологї Східної Украӥни, 9, с. 137-197.

Братченко, С. Н., Санжаров, С. Н. 2001. Рідкісні бронзові знаряддя з катакомб Сіверськодонеччини та Донщини III тис. до н. е. Луганськ: СУНУ ім. В. Даля.

Гак, Е. И. 2005. Металлообрабатывающее производство катакомбных плелен Северного Предкавказья, Нижнего Дона и Северского Дониа. Авторедерат дисертации к. и. н. МГУ им. М. В. Ломоносова. Москва.

Гершкович, Я. П. 1986. Фигурные поясные пряжки культуры многоваликовой керамики. Советская археология, 2, с. 132-146.

Дергачев, В. А. 1986. Молдавия и соседние территории в эпоху бронзы. Кишинёв: Штиинца.

Іванова, С., Тощев, Г. 2018. Бронзова доба ПівнічноЗахідного Причорномор'я: хронологія культур та можливість контактів. Вісник Київського національного університету культури і мистеитв, 2, с. 108-126.

Бочкарев, В. С. (ред.). 1990. Классифбкаиия в археологии. Терлинологический словарь-справочник. Москва.

Клейн, Л. С. 1991. Археологическая типология. Ленинград.

Клейн, Л. С. 1999. Миграция: археологические признаки. Stratum plus, 1, c. 52-71.

Ковалева, И. Ф. 1981. Север Степного Поднепровья в среднем бронзовом веке. Днепропетровск: ДГУ.

Ковалева, И. Ф. 1987а. История населения пограничья лесостепи и степи Левобережного Поднепровья в позднем энеолите - бронзовол веке. Диссертация д. и. н. ИА АН УССР.

Ковалева, И. Ф. 1987b. История населения пограничья лесостепи и степи Левобережного Поднепровья в позднем энеолите - бронзовом веке. Автореферат диссертации д. и. н. ИА АН УССР.

Ковалева, И. Ф. 1988. Культурные комплексы так называемых длинных курганов эпохи бронзы. В: Ковалева, И. Ф. (ред.). Археологические палятники Поднепровья в систеле древностей Восточной Евponы. Днепропетровск, с. 20-33.

Ковалева, И. Ф. 1989. Социальная и духовная культура плелен бронзового века (по материалал Левобережной Украины). Днепропетровск: ДГУ.

Латынин, Б. А. 1964. К вопросу о памятниках с так называемой многоваликовой керамикой. Археологический сборник Государственного Эрлитажа, 6, c. $53-71$.

Литвиненко, Р. А. 1997. Об одной параллели в погребальном обряде скотоводческих племен эпохи бронзы Днепро-Донецкого региона. В: Бурносов, В. Ф. (ред.). Матеріали вузівської наукової конфберенцї̈ профбесорсько-викладацького складу за підсулкали науково-досліднищької роботи. 1. Донецьк: ДГУ, с. 10-13.

Литвиненко, Р.А. 1998а. Наконечники стрел культуры многоваликовой керамики. Эпоха бронзы Доно-Донецкого региона, 4, с. 46-52.

Литвиненко, Р. А. 1998b. Погребения КМК с производственным инвентарем. В: Тощев, Г. Н. (ред.).
Проблель изучения катакомбной культурно-исторической общности (ККИО) и культурно-исторической общности многоваликовой кералики (КИOMK). Запорожье, с. 97-105.

Литвиненко, Р. А. 1999а. Об одном типе посуды культуры многоваликовой керамики (КМК). В: $M a$ теріали археологічної конфберениї "Етнічна історія та культура населення степу та лісостепу Євразї (від кам'яного віку по ранне середньовіччя)". Дніпропетровськ, с. 83-86.

Литвиненко, Р. О. 1999b. Про «зруби» культури багатоваликової кераміки. Доба бронзи Доно-Донецького регіону, 5, с. 58-63.

Литвиненко, Р. А. 2000. Каменная курганная архитектура культуры многоваликовой керамики. В: Крыжицкий, С. Д. (ред.). Археология и древняя архитектура Левобережной Украины и смежных территорий. Донецк, с. 12-19.

Литвиненко, Р. А. 2001. Культура Бабино (многоваликовой керамики) и ее место в системе бронзового века юга Восточной Европы. В: Колев, Ю. И. (ред.). Бронзовый век Восточной Европы: характеристика культур, хронология и периодизация. Самapa, c. 161-169.

Литвиненко, Р. А. 2002. Катакомбное наследие в бабинской культуре. В: Степи Евразии в древности и средневековье. Материаль международной научной конферениии, посвященной 100-летию М. П. Грязнова. 1. Санкт-Петербург: Государственный Эрмитаж, с. 183-190.

Литвиненко, Р. А. 2004а. Восточная периферия бабинского очага культурогенеза. В: Проблель археологии Нижнего Поволжья Тезись докладов I международной Нижневолжской археологической конфберениии. Волгоград, с. 102-108.

Литвиненко, Р. А. 2004b. Деревянная посуда культуры Бабино. Донецкий археологический сборник, 11, с. 20-54.

Литвиненко, Р. О. 2005а. До проблеми металовиробництва культури Бабине. В: Проблеми гірничої археологї: Матеріали II міжнародного Карталиського польового археологічного селінару. Алчевськ: ДонДТУ, с. 119-125.

Литвиненко, Р. О. 2005b. Культури бабинська i лолінська: до проблеми контактів. В: Проблели дослідження пал'яток археологї Східної України. Матеріали II-ї Луганської міжнародної історикоархеологічної конферениї̈. Луганськ: Шлях, с. 7578.

Литвиненко, Р. О. 2005с. Поховання культурного кола Бабине з астрагалами. Старожитності 2005, c. $74-86$.

Литвиненко, Р. А. 2006а. Опыт выявления пространственно-семантических структур в погребальном обряде культуры Бабино. Структурно-селиотические исследования в археологии, 3, с. 215-236.

Литвиненко, Р. О. 2006b. Поховання культурного кола Бабине з металевими ножами. Донецький археологічний збірник, 12, с. 32-61.

Литвиненко, Р. О. 2007а. Обставини і чинники бабинської культурогенези. Вісник Донецького університету, 1-2, с. 109-116.

Литвиненко, Р. О. 2007b. Статево-вікова диференціація в поховальному обряді бабинських культур. Матеріали та дослідження з археологї̈ Східної України, 7: від неоліту до кіммерійців, с. 156-172.

Литвиненко, Р. О. 2009а. Генеза, розвиток та історична доля культурного кола Бабине. Maтеріали та дослідження з археологї Східної України, 9, c. $44-90$. 
Литвиненко, Р. О. 2009b. Культурне коло Бабине (за матеріалали поховальних пал'яток). Авторефрерат дисертації д. і. н. IA НАН України.

Литвиненко, Р. А. 2009с. Обстоятельства и факторы бабинского культурогенеза. Археология восточноевропейской лесостепи, с. 11-18.

Литвиненко, Р. О. 2010а. До витоків архітектури довгих могил Надчорномор'я. Донецький археологічний збірник, 13-14, с. 30-66.

Литвиненко, Р.А. 2010b. Культурный круг Бабино: опыт культурогенетических исследований. В: Третий Российский культурологический конгресс с международным участиел "Креативность в пространстве традиции и инновации»: тезисы докладов и сообщений. Санкт-Петербург: Эйдос, с. 42-43.

Литвиненко, Р. О. 2011а. Бабинська культура на перехресті Кавказького і Карпато-Дунайського імпульсів культурогенези. В: Матеріали науковоі конфберениї профбесорського-викладацького складу, наукових співробітників і аспірантів ДонНУ за підсулкали науково-дослідної роботи за період 2009 2010 рp. Донецьк: Цифрова типографрія, с. 249-250.

Литвиненко, Р. О. 2011b. Донецько-донський катакомбний компонент у бабинській культурогенезі. Матеріали та дослідження з археологї̈ Східної $У_{\kappa}$ раїни, 11, с. 179-200.

Литвиненко, Р. О. 2011с. Культурне коло Бабине: досвід культурогенетичних досліджень в археології. Iсторичні і політологічні дослідження, 1-2 (47$48)$, с. $169-178$.

Литвиненко, Р. О. 2011d. Обряд перепоховання в культурах бабинського кола. Донецький археологічний збірник, 15, с. 7-35.

Литвиненко, Р. О. 2012. Північ у поховальній обрядовості людності дніпро-донської бабинської культури. В: Отрощенко, В. В. (ред.). Проблеми дослідження пал'яток археологї Східної Украӥни. Матеріали ІІІ Луганської міжнародної історикоархеологічної коноберениї, присвяченої пал'яті C. Н. Братченка. Луганськ, с. 262-271.

Литвиненко, Р. А. 2013. Культурный круг Бабино: опыт культурогенетических исследований в археологии. В: Бондарев, А. В. (ред.). Культурогенез и культурное наследие. Санкт-Петербург: Эйдос, c. $372-380$.

Литвиненко, Р. 2015. Поховання культурного кола Бабине з виробничим реманентом. Наукові студіï, 8, с. 113-136.

Литвиненко, Р. О. 2016. Керамічний посуд в поховальній обрядовості бабинських культур. В: Балабанов, К. В. (ред.). Україна у світоволу історичнолу просторі. Збірник матеріалів Всеукраӥнської науково-практичної конфберенцї̈. Маріуполь: МДУ, c. 209-213.

Литвиненко, Р. О. 2017. Дніпро-донська бабинська культура: традиції, інновації чи міграції? В: Miграцї та інновацї̈: у пошуках первинності ідей, ре чей і людей. Львів; Винники, с. 19-20.

Литвиненко, Р. А. 2019. Война в посткатакомбном мире. Strarum plus, 2: Вражда и ваджра: сила и слава праистории, с. 313-334.

Литвиненко, Р. О. 2020а. Неординарне поховання бронзового віку з гирлигою: культурно-хронологічна оцінка. В: Отрощенко, В. В., Тощев, Г. М. (ред.). Пологівський посох: досвід міждисииплінарного вивчення. Київ; Запоріжжя, с. 88-102.

Литвиненко, Р. А. 2020b. Посткатакомбная эпоха Восточной Европы: миграции или военные походы. Strarum plus, 2: Узы невозврата. Праисторические миграции в потоке культуры, с. 333-357.
Макаревич, А. В. 2009. Довгі могили бабинської спільноти. Maricmepiyл, 36: Археологічні студії, c. 27-33.

Массон, В. М. 1991. Феномен культуры и культурогенез древних обществ. Археологические изыскания, 1: Археологические культуры и культурная трансформация. Материалы методологического семинара ЛОИА АН СССР, с. 5-10.

Массон, В. М. 2000. Процессы культурной трансформации в доскифрских обществах Восточной Европы. Археологические изыскания, 63: Древние общества юга Восточной Европы в эпоху палеометалла (ранние комплексные общества и вопросы культурной трансформации), с. 5-14.

Мимоход, Р.А. 2005. Блок посткатакомбных культурных образований (постановка проблемы). В: Отрощенко, В. В. (ред.). Проблели дослідження пам'яток археологї̈ Східної України. Луганськ: Шлях, с. 70-74.

Мимоход, Р. А. 2013. Лолинская культура. Северо-западный прикаспий на рубеже среднего и позднего периодов бронзового века. Материалы охранных археологических исследований, 16. Москва: ИА PAH.

Мимоход, Р. А. 2018. Палеоклимат и культурогенез в Восточной Европе в конце III тыс. до н. э. Российская археология, 2, с. 33-48.

Отрощенко, В. В. 1992. О ранней обрядовой группе погребений культуры многоваликовой керамики. В: История и археология Слободской Украинь. Тезись докладов и сообщений Всеукраинской конфберениии. Харьков, с. 163-165.

Отрощенко, В.В. 1996. Южноуральский очаг культурогенеза на оси пассионарных толчков. ДоноДонецкий регион в систеле древностей эпохи бронзы восточноевропейской степи и лесостепи, 2, с. 2931.

Отрощенко, В. В. 1998. К вопросу о доно-волжской абашевской культуре. Археология восточноевропейской лесостепи, 11: Доно-Донецкий регион в эпоху средней и поздней бронзы, с. 52-59.

Отрощенко, В. В. 2002. Історія племен зрубноі спільності. Автореферат дисертації д. і. н. ІА НАН України.

Отрощенко, В.В.2003. К истории племен срубной общности. Археология восточноевропейской лесоcтепи, 17: Доно-Донецкий регион в эпоху бронзы, c. $68-96$.

Отрощенко, В.В. 2005. Колісниці бабинської культури в графрічному та рельедному відтворенні. Матеріали та дослідження з археології Східної $У_{\kappa}$ раїни, 4, с. 235-242.

Отрощенко, В. В. 2020. Пологівська терлига: стратиграфія, культурна належність, семантика. В: Отрощенко, В. В., Тощев, Г. М. (ред.). Пологівський посох: досвід міждисииплінарного вивчення. Київ; Запоріжжя, с. 128-153.

Писларий, И. А. 1983. Культура многоваликовой кералики Восточной Украины. Авторедерат диссертации к. и. н. МГУ.

Писларий, И.А. 1991. Погребальный обряд племён культуры многоваликовой керамики. В: Древняя история населения Украины. Киев, с. 5266.

Пряхин, А. Д., Захарова, Е. Ю. 1996. Знаки на сосудах средней бронзы Доно-Донецкого региона. В: Доно-Донеикий регион в систеле древностей эпохи бронзы восточноевропейской степи и лесостепи. Тезисы докладов и материалов конфберениии. Воронеж: ВГУ, с. 58-63. 
Рогудеев, В. В. 2018. Редкое срубное погребение с игральными костями. В: XXX Крупновские чтения: Кавказ в системе культурных связей Евразии в древности и средневековье. Карачаевск, с. 135-138.

Санжаров, С. Н. 2010. Восточная Украина на рубеже эпох средней - поздней бронзы. Луганск: ВУНУ им. В. Даля.

Черных, Л.А. 1995. Проблемы изучения меднобронзового производства культуры многоваликовой керамики. В: Эпоха бронзы Доно-Донеикого региона. Материаль украинско-российского полевого археологического селинара. Луганск, с. 15-16.

Черняков, И. Т. 1996. Культура многоваликовой керамики - восточный ареал балкано-дунайского очага культурогенеза. В: Горбов, В. Н. (ред.). Северо-Восточное Приазовье в систеле евразийских древностей (энеолит - бронзовый век). Материаль международной конфберениии в 2-х ч. 1. Донецк, c. 59-64.

Grigoriev, S. A. 2002. Ancient Indo-Europeans. Chelyabinsk: Rifei.

Grigoriev, S. 2019. Central European Impulses in Eastern Europe in the Early Second Millennium BC. Slovenská archeológia, LXVII, 2, p. 225-239.

Lytvynenko, R. O. 2013. Central European parallels to the Dnieper-Don centre of Babyno Culture. Baltic-Pontic studies, 18: The Ingul-Donets early bronze civilization as springboard for transmission of Pontic cultural patterns to the Baltic drainage basin. 32001750 BC, p. 121-138.

Pâslaru, I. 2006. Cultura Delacău-Babino. Mangalia: Callasprint.

Stuchlik, S. 2000. Únětická kultura a epišňůrový kulturni okruh na Moravě. In: Rydzewski, J. (ed.). 150 lat Muzeum Archeologicznego w Krakowie. Kraków, s. 281-292.

\section{REFERENCES}

Berezanskaia, S. S. 1979. Osnovnye rezultaty izucheniia kultury mnogovalikovoi keramiki. In: Moruzhenko, A. A. (ed.). Problemy epokhi bronzy iuga Vostochnoi Evropy. Donetsk, s. 4-6.

Berezanskaia, S. S. 1986. Kultura mnogovalikovoi keramiki. In: Artemenko, I. I. (ed.). Kultury epokhi bronzy na territorii Ukrainy. Kiev: Naukova dumka, s. 5-43.

Bratchenko, S. N. 1971. Pam'iatky bahatovalykovoi keramiky. In: Bibikov, S. M. (ed.). Arkheolohiia Ukrainskoi $R S R$ : v 3 t. 1. Kyiv: Naukova dumka, s. 334-344.

Bratchenko, S. N. 1976. Nizhnee Podone v epokhu srednei bronzy. Kiev: Naukova dumka.

Bratchenko, S. N. 1977. K voprosu o slozhenii babinskoi kultury (mnogovalikovoi keramiki). In: Telegin, D. Ia. (ed.) Vilnianskie kurgany v Dneprovskom Nadporozhe. Kiev: Naukova dumka, s. 21-42.

Bratchenko, S. N. 1985. Kultura mnogovalikovoi keramiki. In: Artemenko, I. I. (ed.). Arkheologiia Ukrainskoi SSR: v 3 t. 1. Kiev: Naukova dumka, s. 451-458.

Bratchenko, S. N. 1995a. Priazhki epokhi pozdnei bronzy i ikh severokavkazskie formy. In: Masson, V. M. (ed.). Konvergentsiia $i$ divergentsiia $v$ razvitii kultur epokhi eneolita bronzy Srednei i vostochnoi Evropy. Materialy konferentsii: $v$ $2 \mathrm{ch}$. II. Sankt-Peterburg, s. 8-26.

Bratchenko, S. N. 1995b. Sootnoshenie kamennoi i bronzovoi industrii v eneolite i bronzovom veke. Donskie drevnosti, 4, s. 79-92.

Bratchenko, S. N. 2004. Pradavnia Slobozhanshchina: Svativski mogili-kurgani III tis. do n. e. ta maidani. Materialy ta doslidzhennia $z$ arkheolohii Skhidnoi Ukrainy, 2, s. 65 190.

Bratchenko, S. N. 2006. Leventsovskaia krepost. Pamiatnik kultury bronzovogo veka. Materialy ta doslidzhennia z arkheolohii Skhidnoi Ukrainy, 6. Luhansk: SUNU im. V. Dalia.
Bratchenko, S. N. 2008. Oleksandrivski mohyly-kurhany $\mathrm{v}$ dolyni Luhani. Materialy ta doslidzhennia $z$ arkheolohii Skhidnoi Ukrainy, 8, s. 134-217.

Bratchenko, S. N. 2009. Mykolaivski mohyly-kurhany v ponyzzi r. Luhanka. Materialy ta doslidzhennia $z$ arkheolohii Skhidnoi Ukrainy, 9, s. 137-197.

Bratchenko, S. N., Sanzharov, S. N. 2001. Ridkisni bronzovi znariaddia z katakomb Siverskodonechchyny ta Donshchyny III tys. do n. e. Luhansk: SUNU im. V. Dalia.

Gak, E. I. 2005. Metalloobrabatyvaiushchee proizvodstvo katakombnykh plemen Severnogo Predkavkazia, Nizhnego Dona $i$ Severskogo Dontsa. Avtoreferat disertatsii k. i.n. MGU im. M. V. Lomonosova. Moskva.

Gershkovich, Ia. P. 1986. Figurnye poiasnye priazhki kultury mnogovalikovoi keramiki. Sovetskaia arkheologiia, 2, s. $132-146$.

Dergachev, V. A. 1986. Moldaviia $i$ sosednie territorii $v$ epokhu bronzy. Kishinev: Shtiintsa.

Ivanova, S., Toshchev, H. 2018. Bronzova doba PivnichnoZakhidnoho Prychornomor'ia: khronolohiia kultur ta mozhlyvist kontaktiv. Visnyk Kyivskoho natsionalnoho universytetu kultury i mystetstv, 2, s. 108-126.

Bochkarev, V. S. (ed.). 1990. Klassifikatsiia v arkheologii. Terminologicheskii slovar-spravochnik. Moskva.

Klein, L. S. 1991. Arkheologicheskaia tipologiia. Leningrad.

Klein, L. S. 1999. Migratsiia: arkheologicheskie priznaki. Stratum plus, 1, s. 52-71.

Kovaleva, I. F. 1981. Sever Stepnogo Podneprovia v srednem bronzovom veke. Dnepropetrovsk: DGU.

Kovaleva, I. F. 1987a. Istoriia naseleniia pogranichia lesostepi $i$ stepi Levoberezhnogo Podneprovia v pozdnem eneolite - bronzovom veke. Dissertatsiia d. i. n. IA AN USSR

Kovaleva, I. F. 1987b. Istoriia naseleniia pogranichia lesostepi $i$ stepi Levoberezhnogo Podneprovia v pozdnem eneolite - bronzovom veke. Avtoreferat dissertatsii d. i. n. IA AN USSR.

Kovaleva, I. F. 1988. Kulturnye kompleksy tak nazyvaemykh dlinnykh kurganov epokhi bronzy. In: Kovaleva, I. F. (ed.). Arkheologicheskie pamiatniki Podneprovia v sisteme dreunostei Vostochnoi Evropy. Dnepropetrovsk, s. 20-33.

Kovaleva, I. F. 1989. Sotsialnaia i dukhovnaia kultura plemen bronzovogo veka (po materialam Levoberezhnoi Ukrainy). Dnepropetrovsk: DGU.

Latynin, B. A. 1964. K voprosu o pamiatnikakh s tak nazyvaemoi mnogovalikovoi keramikoi. Arkheologicheskii sbornik Gosudarstvennogo Ermitazha, 6, s. 53-71.

Litvinenko, R. A. 1997. Ob odnoi paralleli v pogrebalnom obriade skotovodcheskikh plemen epokhi bronzy DneproDonetskogo regiona. In: Burnosov, V. F. (ed.). Materialy vuzivskoi naukovoi konferentsii profesorsko-vykladatskoho skladu za pidsumkamy naukovo-doslidnytskoi roboty. 1. Donetsk: DHU, s. 10-13.

Litvinenko, R.A. 1998a. Nakonechniki strel kultury mnogovalikovoi keramiki. Epokha bronzy Dono-Donetskogo regiona, 4 , s. 46-52.

Litvinenko, R. A. 1998b. Pogrebeniia KMK s proizvodstvennym inventarem. In: Toshchev, G. N. (ed.). Problemy izucheniia katakombnoi kulturno-istoricheskoi obshchnosti (KKIO) i kulturno-istoricheskoi obshchnosti mnogovalikovoi keramiki (KIOMK). Zaporozhe, s. 97-105.

Litvinenko, R. A. 1999a. Ob odnom tipe posudy kultury mnogovalikovoi keramiki (KMK). In: Materialy arkheolohichnoi konferentsii "Etnichna istoriia ta kultura naselennia stepu ta lisostepu Yevrazii (vid kam'ianoho viku po rannie serednovichchia)». Dnipropetrovsk, s. 83-86.

Lytvynenko, R. O. 1999b. Pro "zruby» kultury bahatovalykovoi keramiky. Doba bronzy Dono-Donetskoho rehionu, 5 , s. $58-63$.

Litvinenko, R. A. 2000. Kamennaia kurgannaia arkhitektura kultury mnogovalikovoi keramiki. In: Kryzhitskii, S. D. (ed.). Arkheologiia $i$ drevniaia arkhitektura Levoberezhnoi Ukrainy i smezhnykh territorii. Donetsk, s. 12-19.

Litvinenko, R. A. 2001. Kultura Babino (mnogovalikovoi keramiki) i ee mesto $\mathrm{v}$ sisteme bronzovogo veka iuga Vostochnoi Evropy. In: Kolev, Yu. I. (ed.). Bronzovyi vek Vostochnoi Evropy: kharakteristika kultur, khronologiia i periodizatsiia. Samara, s. 161-169. 
Litvinenko, R. A. 2002. Katakombnoe nasledie v babinskoi kulture. In: Stepi Evrazii v drevnosti i srednevekove. Materialy mezhdunarodnoi nauchnoi konferentsii, posviashchenno 100-letiiu M. P. Griaznova. 1. Sankt-Peterburg: Gosudarstvennyi Ermitazh, s. 183-190.

Litvinenko, R. A. 2004a. Vostochnaia periferiia babinskogo ochaga kulturogeneza. In: Problemy arkheologii Nizhnego Povolzhia Tezisy dokladov I mezhdunarodnoi Nizhnevolzhskoi arkheologicheskoi konferentsii. Volgograd, s. 102-108.

Litvinenko, R. A. 2004b. Dereviannaia posuda kultury Babino. Donetskii arkheologicheskii sbornik, 11, s. 20-54.

Lytvynenko, R. O. 2005a. Do problemy metalovyrobnytstva kultury Babyne. In: Problemy hirnychoi arkheolohii: Materialy II mizhnarodnoho Kartamyskoho polovoho arkheolohichnoho seminaru. Alchevsk: DonDTU, s. 119-125.

Lytvynenko, R. O. 2005b. Kultury babynska i lolinska: do problemy kontaktiv. In: Problemy doslidzhennia pam̋̈atok arkheolohii Skhidnoi Ukrainy. Materialy II-i Luhanskoi mizhnarodnoi istoryko-arkheolohichnoi konferentsii. Luhansk: Shliakh, s. 75-78.

Lytvynenko, R. O. 2005c. Pokhovannia kulturnoho kola Babyne z astrahalamy. Starozhytnosti 2005, s. 74-86.

Litvinenko, R. A. 2006a. Opyt vyiavleniia prostranstvenno-semanticheskikh struktur v pogrebalnom obriade kultury Babino. Strukturno-semioticheskie issledovaniia v arkheologii, 3, s. 215-236.

Lytvynenko, R. O. 2006b. Pokhovannia kulturnoho kola Babyne z metalevymy nozhamy. Donetskyi arkheolohichnyi zbirnyk, 12 , s. 32-61.

Lytvynenko, R. O. 2007a. Obstavyny i chynnyky babynskoi kulturogenezy. Visnyk Donetskoho universytetu, 1-2, s. $109-116$.

Lytvynenko, R. O. 2007b. Statevo-vikova dyferentsiatsiia v pokhovalnomu obriadi babynskykh kultur. Materialy ta doslidzhennia $z$ arkheolohii Skhidnoi Ukrainy, 7: vid neolitu do kimmeriitsiv, s. 156-172.

Lytvynenko, R. O. 2009a. Geneza, rozvytok ta istorychna dolia kulturnoho kola Babyne. Materialy ta doslidzhennia z arkheolohii Skhidnoi Ukrainy, 9, s. 44-90.

Lytvynenko, R. O. 2009b. Kulturne kolo Babyne (za materialamy pokhovalnykh pam’iatok). Avtoreferat dysertatsii d. i. n. IA NAN Ukrainy.

Litvinenko, R. A. 2009c. Obstoiatelstva i faktory babinskogo kulturogeneza. Arkheologiia vostochnoevropeiskoi lesostepi, s. 11-18,

Lytvynenko, R. O. 2010a. Do vytokiv arkhitektury dovhykh mohyl Nadchornomor'ia. Donetskyi arkheolohichnyi zbirnyk, 13-14, s. 30-66.

Litvinenko, R. A. 2010b. Kulturnyi krug Babino: opyt kulturogeneticheskikh issledovanii. In: Tretii Rossiiskii kulturologicheskii kongress s mezhdunarodnym uchastiem "Kreativnost $v$ prostranstve traditsii $i$ innovatsiin: tezisy dokladov $i$ soobshchenii. Sankt-Peterburg: Eidos, s. 42-43.

Lytvynenko, R. O. 2011a. Babynska kultura na perekhrest Kavkazkoho i Karpato-Dunaiskoho impulsiv kulturogenezy. In: Materialy naukovoi konferentsii profesorskoho-vykladatskoho skladu, naukovykh spivrobitnykiv $i$ aspirantiv DonNU za pidsumkamy naukovo-doslidnoi roboty za period 20092010 rr. Donetsk: Tsyfrova typohrafiia, s. 249-250.

Lytvynenko, R. O. 2011b. Donetsko-donskyi katakombnyi komponent u babynskii kulturogenezi. Materialy ta doslidzhennia $z$ arkheolohii Skhidnoi Ukrainy, 11, s. 179-200.

Lytvynenko, R. O. 2011c. Kulturne kolo Babyne: dosvid kulturohenetychnykh doslidzhen $\mathrm{v}$ arkheolohii. Istorychni politolohichni doslidzhennia, 1-2 (47-48), s. 169-178.

Lytvynenko, R. O. 2011d. Obriad perepokhovannia v kulturakh babynskoho kola. Donetskyi arkheolohichnyi zbirnyk, 15 , s. 7-35.

Lytvynenko, R. O. 2012. Pivnich u pokhovalnii obriadovosti liudnosti dnipro-donskoi babynskoi kultury. In: Otroshchenko, V. V. (ed.). Problemy doslidzhennia pam’iatok arkheolohii Skhidnoi Ukrainy. Materialy III Luhanskoi mizhnarodnoi istoryko-arkheolohichnoi konferentsii, prysviachenoi pam'iati S. N. Bratchenka. Luhansk, s. 262-271.

Litvinenko, R. A. 2013. Kulturnyi krug Babino: opyt kulturogeneticheskikh issledovanii $\mathrm{v}$ arkheologii. In: Bondarev, A. V. (ed.). Kulturogenez $i$ kulturnoe nasledie. Sankt-Peterburg: Eidos, s. 372-380.
Lytvynenko, R. 2015. Pokhovannia kulturnoho kola Babyne z vyrobnychym remanentom. Naukovi studii, 8, s. 113136.

Lytvynenko, R. O. 2016. Keramichnyi posud v pokhovalnii obriadovosti babynskykh kultur. In: Balabanov, K. V. (ed.) Ukraina u svitovomu istorychnomu prostori. Zbirnyk materialiv Vseukrainskoi naukovo-praktychnoi konferentsii. Mariupol: MDU, s. 209-213.

Lytvynenko, R. O. 2017. Dnipro-donska babynska kultura: tradytsii, innovatsii chy mihratsii? In: Mihratsii ta innovatsii: u poshukakh pervynnosti idei, rechei i liudei. Lviv; Vynnyky, s. $19-20$.

Litvinenko, R. A. 2019. Voina v postkatakombnom mire. Strarum plus, 2: Vrazhda i vadzhra: sila i slava praistorii, s. 313-334.

Lytvynenko, R. O. 2020a. Neordynarne pokhovannia bronzovoho viku z gyrlygoiu: kulturno-khronolohichna otsinka. In: Otroshchenko, V. V., Toshchev, H. M. (eds.). Polohivskyi posokh: dosvid mizhdystsyplinarnoho vyvchennia. Kyiv; Zaporizhzhia, s. 88-102

Litvinenko, R. A. 2020b. Postkatakombnaia epokha Vostochnoi Evropy: migratsii ili voennye pokhody. Strarum plus, 2: Uzy nevozvrata. Praistoricheskie migratsii v potoke kultury, s. 333-357.

Makarevych, A. V. 2009. Dovhi mohyly babynskoi spilnoty. Magisterium, 36: Arkheolohichni studii, s. 27-33.

Masson, V. M. 1991. Fenomen kultury i kulturogenez drevnikh obshchestv. Arkheologicheskie izyskaniia, 1: Arkheologicheskie kultury i kulturnaia transformatsiia. Materialy metodologicheskogo seminara LOIA AN SSSR, s. 5-10.

Masson, V. M. 2000. Protsessy kulturnoi transformatsi v doskifskikh obshchestvakh Vostochnoi Evropy. Arkheologicheskie izyskaniia, 63: Drevnie obshchestva iuga Vostochnoi Evropy v epokhu paleometalla (rannie kompleksnye obshchestva i voprosy kulturnoi transformatsii), s. 5-14.

Mimokhod, R. A. 2005. Blok postkatakombnykh kulturnykh obrazovanii (postanovka problemy). In: Otroshchenko, V. V. (ed.). Problemy doslidzhennia pam'iatok arkhe. olohii Skhidnoi Ukrainy. Luhansk: Shliakh, s. 70-74.

Mimokhod, R. A. 2013. Lolinskaia kultura. Severo-zapadnyi prikaspii na rubezhe srednego $i$ pozdnego periodov bronzovogo veka. Materialy okhrannykh arkheologicheskikh issledovanii, 16. Moskva: IA RAN.

Mimokhod, R. A. 2018. Paleoklimat i kulturogenez v Vostochnoi Evrope v kontse III tys. do n. e. Rossiiskaia arkheologiia, 2, s. 33-48.

Otroshchenko, V. V. 1992 O rannei obriadovoi gruppe pogrebenii kultury mnogovalikovoi keramiki. In: Istoriia $i$ arkheologiia Slobodskoi Ukrainy. Tezisy dokladov $i$ soobshchenii Vseukrainskoi konferentsii. Kharkov, s. 163-165.

Otroshchenko, V. V. 1996. Iuzhnouralskii ochag kulturogeneza na osi passionarnykh tolchkov. Dono-Donetskii region $v$ sisteme drevnostei epokhi bronzy vostochnoevropeiskoi stepi i lesostepi, 2, s. 29-31.

Otroshchenko, V. V. 1998. K voprosu o dono-volzhskoi abashevskoi kulture. Arkheologiia vostochnoevropeiskoi lesostepi, 11: Dono-Donetskii region v epokhu srednei i pozdnei bronzy, s. 52-59.

Otroshchenko, V. V. 2002. Istoriia plemen zrubnoi spilnos$t i$. Avtoreferat dysertatsii d. i. n. IA NAN Ukrainy.

Otroshchenko, V. V. 2003. K istorii plemen srubnoi obshchnosti. Arkheologiia vostochnoevropeiskoi lesostepi, 17: Dono-Donetskii region v epokhu bronzy, s. 68-96.

Otroshchenko, V. V. 2005. Kolisnytsi babynskoi kultury v hrafichnomu ta reliefnomu vidtvorenni. Materialy ta doslidzhennia $z$ arkheolohii Skhidnoi Ukrainy, 4, s. 235-242.

Otroshchenko, V. V. 2020. Polohivska gerlyga: stratyhrafiia, kulturna nalezhnist, semantyka. In: Otroshchenko, V. V., Toshchev, H. M. (eds.). Polohivskyi posokh: dosvid mizhdystsyplinarnoho vyvchennia. Kyiv; Zaporizhzhia, s. 128-153.

Pislarii, I. A. 1983. Kultura mnogovalikovoi keramiki Vostochnoi Ukrainy. Avtoreferat dissertatsii k. i. n. MGU.

Pislarii, I. A. 1991. Pogrebalnyi obriad plemen kultury mnogovalikovoi keramiki. In: Drevniaia istoriia naseleniia Ukrainy. Kiev, s. 52-66.

Priakhin, A. D., Zakharova, E. Iu. 1996. Znaki na sosudakh srednei bronzy Dono-Donetskogo regiona. In: Dono-Donetskii region v sisteme dreunostei epokhi bronzy vostochnoevropeiskoi 
stepi i lesostepi. Tezisy dokladov i materialov konferentsii. Voronezh: VGU, s. 58-63.

Rogudeev, V. V. 2018. Redkoe srubnoe pogrebenie s igralnymi kostiami. In: XXX Krupnovskie chteniia: Kavkaz v sisteme kulturnykh sviazei Evrazii $v$ drevnosti $i$ srednevekove. Karachaevsk, s. 135-138.

Sanzharov, S. N. 2010. Vostochnaia Ukraina na rubezhe epokh srednei - pozdnei bronzy. Lugansk: VUNU im. V. Dalia.

Chernykh, L. A. 1995. Problemy izucheniia medno-bronzovogo proizvodstva kultury mnogovalikovoi keramiki. In: Epokha bronzy Dono-Donetskogo regiona. Materialy ukrainsko-rossiiskogo polevogo arkheologicheskogo seminara. Lugansk, s. 15-16.

Cherniakov, I. T. 1996. Kultura mnogovalikovoi keramiki - vostochnyi areal balkano-dunaiskogo ochaga kulturogeneza. In: Gorbov, V. N. (ed.). Severo-Vostochnoe Priazove $v$ sisteme evraziiskikh drevnostei (eneolit - bronzovyi vek). Materialy mezhdunarodnoi konferentsii $v 2-k h$ ch. 1. Donetsk, s. 59-64.

Grigoriev, S. A. 2002. Ancient Indo-Europeans. Chelyabinsk: Rifei.

Grigoriev, S. 2019. Central European Impulses in Eastern Europe in the Early Second Millennium BC. Slovenská archeológia, LXVII, 2, p. 225-239.

Lytvynenko, R. O. 2013. Central European parallels to the Dnieper-Don centre of Babyno Culture. Baltic-Pontic studies, 18: The Ingul-Donets early bronze civilization as springboard for transmission of Pontic cultural patterns to the Baltic drainage basin. 3200-1750 BC, p. 121-138.

Pâslaru, I. 2006. Cultura Delacău-Babino. Mangalia: Callasprint.

Stuchlik, S. 2000. Únětická kultura a epišňůrový kulturni okruh na Moravě. In: Rydzewski, J. (ed.). 150 lat Muzeum Archeologicznego w Krakowie. Kraków, s. 281-292.

\section{R. A. Lytuynenko}

\section{BABYNE'S CULTURAL GENESIS}

The problem of the Babyne Culture's origin has been repeatedly raised by Ukrainian scientists. Thus, in the literature you can find about a dozen versions of Babyne's cultural genesis (Братченко 1971; 1976; 1977; 1985; 1995a; 1995b; 2006; Березанская 1979; 1986; Писларий 1983; 1991; Pâslaru 2006; Дергачев 1986; Ковалева 1981; 1987a; 1987b; Черняков 1996; Отрощенко 1996; 1998; 2002; 2003; Grigoriev 2002; Санжаров 2010; Іванова, Тощев 2018). About half of these versions were born more as a result of the authors' intuition than as a result of systematic, comprehensive and painstaking research. The author of these lines also devoted a series of publications to the problem of Babyne's cultural genesis. This article summarizes the results of the author's research of Babyne's cultural genesis, which is not presented in full, but only in its key part - the origin of the primary of the structural units of the Babyne Cultural Circle - Dnieper-Don Babyne Culture (DDBC).

The basic source of research is burial mounds, which, compared to settlements, are better and more fully studied, are more mass, diagnostic in chronological and cultural-taxonomic sense. The archeological ensemble of Babyne cemeteries was initially divided into structural elements at the level of mound construction, burial structures, remains of the deceased, funeral equipment, traces of additional ritual actions, etc. The assessment of the structural components of the DDBC cemeteries shows that this set of elements is not homogeneous and can be divided into three groups, different in origin: I) traditions; II) external influences; III) innovation (figure).

I. Traditions are associated with the preceding local cultural component, mostly the Donets-Don Catacomb Culture and to a lesser extent the Ingul Catacomb Culture: burial «packages», "sets of tools», quivers with arrows, dice, animal «skins» («Head and Hooves»), certain types of metal axes and knives, stone maces and axes, wooden ware and boxes, wooden crooks, ceramic ware from a triangle-parquet-fir decor, ceramic amphorae and hemispherical bowls, faience beads with warts, bone ring buckles, etc. (figure: I).

II. External influences have no local roots in Eastern Europe but find clear complex analogies in the cultures / groups of the Early Bronze Age in Central and South-Eastern Europe. All these effects relate to certain features of the burial ceremony, the headset jewelry and clothing decoration: gender opposition of the dead, copper-bronze neck ring, arm-spirals, double spiral pendants, spiral and tin tubes, disc plate with punch ornament, hemispherical platelets with two holes, pendant of Canis holes, buckles with a hook, wrist-guards (figure: II). This subcomplex allows to synchronize DDBC with the cultures of Central Europe of the Reineke's Br A1b-A2a.

III. Innovations include such components of the cultural complex of DDBC, which can't be associated with local cultural substrate and external influences: specific mound construction (long mounds, stone architecture), the location of secondary graves in the northern semicircle of the mound, wooden tombs and stone cysts, specific ceramic vessels, original system of ornament-signs, etc. (figure: III).

The three selected blocks are different in nature and origins and are understood by us as constituent elements of DDBC genesis. The basic substrate for the formation of the DDBC was the aboriginal component of the late Catacomb Culture, which began to transform into the DDBC thanks to an external catalyst from Central Europe (Unetice culture and related groups). This impulse from Central Europe to Eastern Europe can be linked to either migration or missionary cultural leaders. It should be borne in mind that these processes took place against the background of a global climate catastrophe with its maximum around $2200 \mathrm{BC}$.

Keywords: cultural genesis, Bronze Age, Babyne Cultural Circle, Eastern and Central Europe.

Одержано 1.11.2020

ЛИТВИНЕНКО Роман Олександрович, доктор історичних наук, профресор, Донецький національний університет імені Василя Стуса, Вінниця, Україна.

LYTVYNENKO Roman A., D. Sc., professor, Vasyl' Stus Donetsk National University, Vinnytsia, Ukraine. ORCID: 0000-0003-2034-4305,

e-mail: ltvnrmn@gmail.com. 